\title{
The Role of an Individual's Perception of their Partner's Oral Health in Heterosexual Couples
}

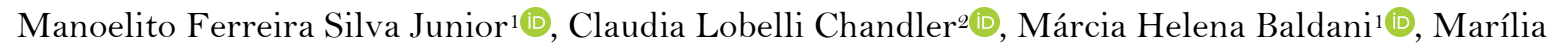 \\ Jesus Batista ${ }^{3}$ (I), Maria da Luz Rosario de Sousa ${ }^{3}$ (i)
}

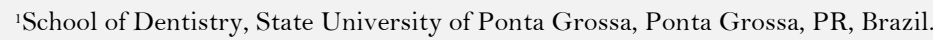

${ }^{2}$ Pennsylvania College, Gettysburg, Pennsylvania, United States.

${ }^{3}$ Department of Health Sciences and Child Dentistry, Piracicaba Dental School, University of Campinas, Piracicaba, SP, Brazil.

Correspondence: Manoelito Ferreira Silva Júnior, Faculdade de Odontologia, Universidade Estadual de Ponta Grossa, Avenida General Carlos Cavalcanti, 4748, Ponta Grossa, Paraná, Brazil. 84030-900. E-mail: manoelito_fsjunior@hotmail.com

\section{Academic Editor: Lucianne Cople Maia de Faria}

Received: 09 November 2020 / Review: 18 February 2021 / Accepted: 04 March 2021

How to cite: Silva Junior MF, Chandler CL, Baldani MH, Batista MJ, Sousa MLR. The role of an individual's perception of their partner's oral health in heterosexual couples. Pesqui Bras Odontopediatria Clín Integr. 2021; $21: e 0237$. https://doi.org/10.1590/pboci.2021.104

\begin{abstract}
Objective: To analyze the role of an individual's perception of their partner's oral health in heterosexual couples. Material and Methods: The exploratory study with a qualitative and quantitative approach and data were collected in households in 2015. The quantitative data were analyzed using simple and multivariate binary logistic regression $(\mathrm{p}<0.05)$, and the qualitative using Thematic Content Analysis. Results: Of 143 participants, $113(79.0 \%)$ were in a relationship and made up the final sample of the present study. Both women and men reported a small percentage of discomfort in relation to their partners' oral health $(23.1 \%$ vs. $14.8 \%$; $=0.199)$, and only a few had received complaints about their own oral health ( $20.7 \%$ vs. $10.7 \% ; \mathrm{p}=0.179$ ). However, almost half of the sample had been told by their partner to see the dentist $(47.6 \%$ vs. $31.0 \%$; $\mathrm{p}=0.156)$, and of these, most were men $(48.3 \%$ vs. $25.0 \%$; $\mathrm{p}=0.022)$. The men that were more likely to be told by their partners to see the dentist ( $\mathrm{OR}=5.82$; 95\% CI: $1.71-19.80$ ) were upperclass (OR=3.35; 95\% CI: 1.05-10.67), workers (OR=7.45; 95\% CI: 1.62-34.20) who were dissatisfied with their oral health (OR=3.45; 95\% CI: 1.13-10.51). The participants' reasons for complaining of their partners' oral health or for telling them to see the dentist were related to physiopathological clinical aspects and healthcare habits. Conclusion: The women told their male partners to seek dental services more often, and future studies should explore whether women are predictors of care and the validity of this information as an indicator of the oral health condition of their male partners.
\end{abstract}

Keywords: Sex; Marriage; Oral Health; Prevalence; Epidemiology. 


\section{Introduction}

The structure of the modern family has changed over the years. Before the modern age, society was mainly rural and the role of women was, in most cases, limited to raising children and performing domestic tasks. However, after the Industrial Revolution, women began to enter the emerging labor market, while still being responsible for taking care of the children and the house [1,2], which may be a symptom of what is still to this day an extremely male-focused society [2].

The male image is stigmatized as strong and created to protect and provide; therefore, taking care of one's own health may be perceived as a sign of fragility, making the act of seeking health services a female task $[3,4]$, i.e., there is a predominance of a hegemonic androcentric perspective of healthcare [5], which could partially justify why men seek care less often compared to women $[4,6]$.

The stigma attached to masculinity and healthcare has gained more attention in recent decades $[5,7]$. For example, an English study found that men sought primary care services 32\% less than women, and the gender gap was greater in routine care, in areas with worse socioeconomic conditions, and among adolescents and older adults [7]. However, there were no gender inequalities among individuals undergoing treatment for diseases that require the use of medications, especially coronary heart disease and depression [7], as also pointed out in a systematic review addressing similar morbidities, even in primary healthcare [8].

Studies show that women take better care of their general [9] and oral health [4,10], and the fact they seek healthcare services more often could be explained by hormonal conditions [10,11], greater prevalence of systemic diseases [10,11], cultural aspects [11,12], and higher aesthetic demands [11,13].

This greater concern with self-care among women is also passed on to their children. A systematic review found that although the attitudes and educational level of both parents had a positive impact on the children's oral health status, the mothers' oral health habits had a greater influence on their oral self-care [14].

A study with older adults raised the hypothesis of the greater use of dental services by married people is due to the influence of one partner on the other $[15,16]$, but it did not address the role of women as predictors of their partners' oral health care. In this context, the objective of this study was to analyze oral health care in heterosexual couples according to sex.

\section{Material and Methods}

Study Design and Ethical Aspects

This exploratory study with a quantitative and qualitative approach was part of the epidemiological survey "Oral Health Cohort of Adults in Piracicaba-SP" conducted in the municipality of Piracicaba, state of São Paulo, Brazil [17]. The quantitative study has a cross-sectional analytical.

This research was approved by the Research Ethics Committee of the School of Dentistry of Piracicaba under protocol No. 177/2009.

\section{Data Sources and Variables}

The data were obtained from the second wave of the study carried out in Piracicaba-SP, and the methodological aspects were published in advance [17]. Data collection was performed in households in 2011, and after probabilistic sampling, 248 adults aged 20-64 years were included in the study. The follow-up was conducted in households in 2015 and had the participation of 143 younger and older adults [17]. However, the inclusion criterion of the present study was being in a heterosexual relationship, and thus, the final sample totaled 113 individuals. 
In addition, only the data from the follow-up questionnaire were used, namely: Sex (male or female); Age (24-48 and 49-68 years); Type of relationship (stable union [married and cohabiting], others [dating and engaged] and no relationship); Time in current relationship ( $\leq 10$ years or $\geq 10$ years); Works (no or yes); Social class (upper or lower middle/lower); Smoking (no or yes); Satisfied with his/her own oral health (very satisfied/satisfied or a little dissatisfied/dissatisfied/very dissatisfied); Satisfied with the appearance of his/her teeth (very satisfied/satisfied or a little dissatisfied/dissatisfied/very dissatisfied); Self-reported quality of life (excellent/very good/good or fair/poor). Social class was assessed according to the classification of Graciano et al. [18], who uses a score system based on education, family income, occupation, type of residence and number of residents in the household, grouping the scores into six social classes. For this study, the classes were grouped into lower, middle and upper.

Six questions about the participants' perception of their partners' oral health and the partners' perception of their own oral health were prepared by the authors themselves, four of which were to be answered on a Likert scale (never, rarely, sometimes, repeatedly or always): “Does your partner's oral health bother you?"; "Have you ever told your partner to see the dentist?", "Does your partner complain of your oral health?"; and "Has your partner ever told you to see the dentist?". Two questions were open-ended: "For what reason did you tell your partner to see the dentist?" and "For what reason did your partner tell you to see the dentist?”. The questions were previously tested among patients of the School of Dentistry of Piracicaba (FOP/Unicamp), without the need for adjustments.

\section{Data Analysis}

The quantitative analysis was performed using the Statistical Package for the Social Sciences (SPSS), version 20.0. Initially, a descriptive analysis was carried out to obtain the absolute and percentage distribution of the variables. The study's dependent variables were: 1) their partner's oral health bothers the participant; 2) the participant had instructed their partner to see the dentist; 3) the participant had received complaints about their oral health from their partner; and, 4) the participant had been told by their partner to see the dentist, and they were dichotomous in: yes (rarely, sometimes, repeatedly or always) or no (never). The study's independent variable of interest was sex (male and female).

The first stage of the inferential analysis consisted of crude binary logistic regressions between the dependent variables and the independent variable of interest, and in the case of association $(\mathrm{p}<0.05)$, new analyses were carried out. In the second stage, crude binary logistic regression was performed with the other independent variables. Variables with $\mathrm{p}<0.20$ were adjusted in the multivariate binary logistic regression until the final model was defined $(\mathrm{p}<0.05)$.

The qualitative analysis followed the thematic content analysis method proposed by Bardin [19], using a set of interpretive techniques that aim to describe and decode the components of a complex system of meanings, and was carried out independently by two researchers, who then developed the themes together. The answers will be expressed with the code for women (W) and men (M), followed by the identification number of the epidemiological survey's form.

\section{Results}

Of the 143 individuals who participated in the cohort study, $113(79.0 \%)$ were eligible and thus included in the present sample. Most participants were younger (50.4\%) upper-class (45.1\%) women (74.3\%) who worked $(73.2 \%)$ and had been in a stable relationship $(95.6 \%)$ for more than 10 years $(77.9 \%)$. In addition, most did not smoke $(87.6 \%)$, were satisfied with their oral health $(62.8 \%)$ and with the appearance of their teeth $(64.3 \%)$, and perceived their quality of life as good (84.1\%) (Table 1$)$. 
Table 1. Demographic characteristics of the population under study.

\begin{tabular}{|c|c|c|}
\hline Variables & $\mathbf{N}$ & $\%$ \\
\hline \multicolumn{3}{|l|}{ Sex } \\
\hline Female & 84 & 74.3 \\
\hline Male & 29 & 25.7 \\
\hline \multicolumn{3}{|l|}{ Age* } \\
\hline Range 1 & 57 & 50.4 \\
\hline Range 2 & 56 & 49.6 \\
\hline \multicolumn{3}{|l|}{ Type of Relationship } \\
\hline Stable union & 108 & 95.6 \\
\hline Other (dating + engaged) & 05 & 4.4 \\
\hline \multicolumn{3}{|l|}{ Time in current relationship } \\
\hline$\leq 10$ years & 25 & 22.1 \\
\hline$\geq 11$ years & 88 & 77.9 \\
\hline \multicolumn{3}{|l|}{ Works** } \\
\hline No & 22 & 26.8 \\
\hline Yes & 60 & 73.2 \\
\hline \multicolumn{3}{|l|}{ Social Class } \\
\hline Lower/Middle & 62 & 52.9 \\
\hline Upper & 51 & 45.1 \\
\hline \multicolumn{3}{|l|}{ Smokes } \\
\hline No & 99 & 87.6 \\
\hline Yes & 14 & 12.4 \\
\hline \multicolumn{3}{|l|}{ Is satisfied with his/her oral health } \\
\hline Yes & 71 & 62.8 \\
\hline No & 42 & 37.2 \\
\hline \multicolumn{3}{|c|}{ Is satisfied with the appearance of his/her teeth** } \\
\hline Yes & 72 & 64.3 \\
\hline No & 40 & 35.7 \\
\hline \multicolumn{3}{|c|}{ Self-perceives his/her quality of life as good } \\
\hline Yes & 95 & 84.1 \\
\hline No & 18 & 15.9 \\
\hline
\end{tabular}

Table 2 shows that $22(21.0 \%)$ of the interviewees had complained of the oral health of their partners, and $49(43.4 \%)$ had instructed their partners to see the dentist. Regarding the partners' perception of the participants' oral health, $15(13.3 \%)$ had received complaints, and 35 (31.0\%) had been advised by their partner to see the dentist.

Table 2. Frequency distribution of the variables under study.

\begin{tabular}{lcc}
\multicolumn{1}{c}{ Variables } & N & \% \\
\hline Does the oral health of your partner bother you? ${ }^{*}$ & & \\
Never & 83 & 79.0 \\
Rarely & 07 & 6.7 \\
Sometimes & 07 & 6.7 \\
Repeatedly & 08 & 7.6 \\
Always & 00 & 0.0 \\
Have you ever told your partner to see the dentist? & & \\
Never & 64 & 56.6 \\
Rarely & 10 & 8.8 \\
Sometimes & 21 & 18.6 \\
Repeatedly & 03 & 2.7 \\
Always & 15 & 13.3 \\
Does your partner complain of your oral health? & & \\
Never & 98 & 86.7 \\
Rarely & 05 & 4.4 \\
Sometimes & 07 & 6.2
\end{tabular}




\begin{tabular}{lcc} 
Repeatedly & OO & 0.0 \\
Always & 03 & 2.7 \\
Has your partner ever told you to see the dentist? & 78 & 69.0 \\
Never & 09 & 8.0 \\
Rarely & 15 & 13.3 \\
Sometimes & 00 & 0.0 \\
Repeatedly & 11 & 9.7 \\
\hline Always
\end{tabular}

*The total is not 113 due to loss of data.

When analyzing the data according to sex, it appears that the women complained of their partners' oral health $(23.1 \%$ vs. $14.8 \%)$ and told them to see the dentist $(47.6 \%$ vs. $31.0 \%)$ more often, while the men reported receiving more complaints $(20.7 \%$ vs. $10.7 \%)$ and were more frequently told by their partners to see the dentist (48.3\% vs. $25.0 \%$ ) (Figure 1$)$.

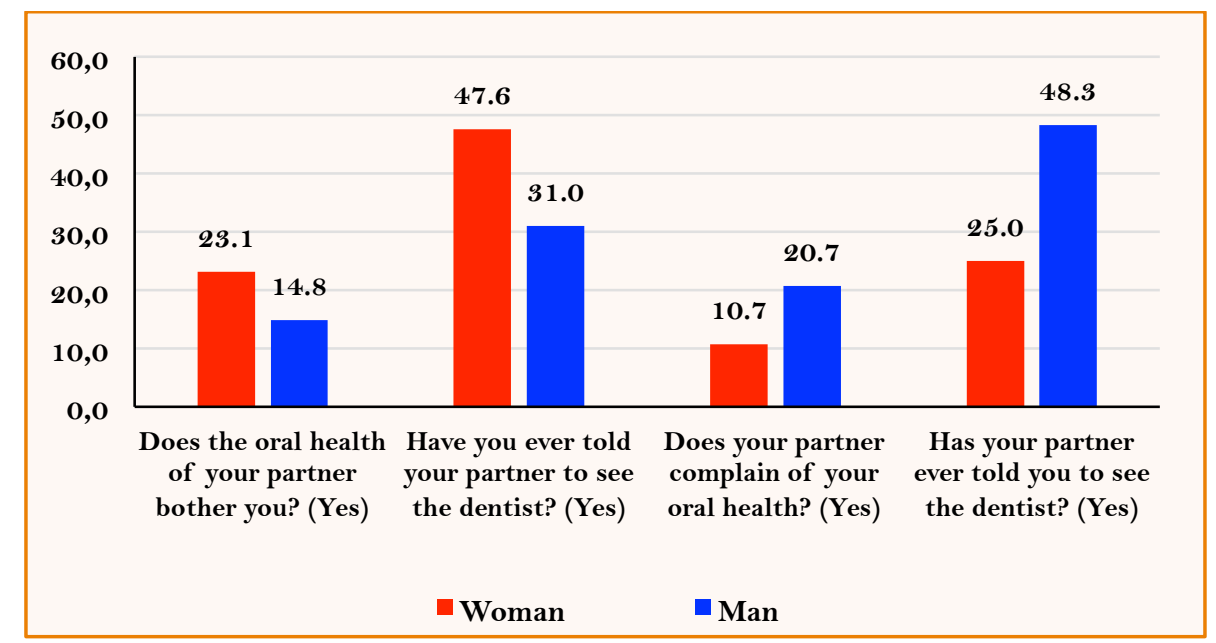

Figure 1. Distribution of frequency and association between the studied variables and gender.

There was no association between sex and complaining of the partner's oral health $(\mathrm{p}=0.199)$, telling the partner to see the dentist $(\mathrm{p}=0.156)$ and not receiving oral-health related complaints from the partner $(\mathrm{p}=0.179)$. However, the men were more likely to be told by their partner to see the dentist $(\mathrm{OR}=2.80 ; 95 \%$ $\mathrm{CI}=1.16-6.75 ; \mathrm{p}=0.022)($ Table 3$)$.

Table 3. Crude analysis between dependent variables and sex.

\begin{tabular}{|c|c|c|c|c|c|c|c|c|c|}
\hline \multirow[b]{2}{*}{ Questions } & \multicolumn{2}{|c|}{ Yes } & \multicolumn{2}{|c|}{ No } & \multicolumn{2}{|c|}{ Total } & \multirow[b]{2}{*}{ Crude OR } & \multirow[b]{2}{*}{$95 \% \mathrm{CI}$} & \multirow[b]{2}{*}{ p-value } \\
\hline & $\mathrm{N}$ & $\%$ & $\mathrm{~N}$ & $\%$ & $\mathrm{~N}$ & $\%$ & & & \\
\hline \multicolumn{10}{|c|}{ Does the oral health of your partner bother you?* } \\
\hline Female & 18 & 23.1 & 60 & 76.9 & 78 & 100.0 & 0.58 & $0.25-1.34$ & \\
\hline Male & 4 & 14.8 & 23 & 85.2 & 27 & 100.0 & 1.00 & & 0.199 \\
\hline \multicolumn{10}{|c|}{ Have you ever told your partner to see the dentist? } \\
\hline Female & 40 & 47.6 & 44 & 52.4 & 84 & 100.0 & 0.52 & $0.21-1.28$ & 0.156 \\
\hline Male & 9 & 31.0 & 20 & 69.0 & 29 & 100.0 & 1.00 & & \\
\hline \multicolumn{10}{|c|}{ Does your partner complain of your oral health? } \\
\hline Female & 9 & 10.7 & 75 & 89.3 & 84 & 100.0 & 2.17 & $0.71-6.76$ & 0.179 \\
\hline Male & 6 & 20.7 & 23 & 79.3 & 29 & 100.0 & 1.00 & & \\
\hline \multicolumn{10}{|c|}{ Has your partner ever told you to see the dentist? } \\
\hline Female & 20 & 25.0 & 63 & 75.0 & 84 & 100.0 & 2.80 & $1.16-6.75$ & 0.022 \\
\hline Male & 14 & 48.3 & 15 & 51.7 & 29 & 100.0 & 1.00 & & \\
\hline
\end{tabular}

*The total is not 113 due to loss of data. 
After adjusting the model, upper-class (OR $=3.35 ; 95 \% \mathrm{CI}: 1.05-10.67)$ men $(\mathrm{OR}=5.82 ; 95 \% \mathrm{CI}: 1.71-$ 19.80) who worked $(\mathrm{OR}=7.45 ; 95 \% \mathrm{CI}: 1.62-34.20)$ and were dissatisfied with their oral health $(\mathrm{OR}=3.45$; 95\% CI: 1.13-10.51) were found to be more likely to be told by their partners to see the dentist (Table 4).

Table 4. Crude and adjusted analysis of the partner's advice to see the dentist and the independent variables.

\begin{tabular}{|c|c|c|c|c|c|c|c|c|c|c|c|}
\hline \multirow{2}{*}{ Variables } & \multicolumn{2}{|c|}{ No } & \multicolumn{2}{|c|}{ Yes } & \multirow{2}{*}{ p-value } & \multirow{2}{*}{$\begin{array}{c}\text { Crude } \\
\text { OR }\end{array}$} & \multirow{2}{*}{$95 \% \mathrm{CI}$} & \multirow{2}{*}{ p-value } & \multirow{2}{*}{$\begin{array}{c}\text { Adjusted } \\
\text { OR }\end{array}$} & \multirow{2}{*}{$95 \%$ CI } & \multirow{2}{*}{ p-value } \\
\hline & $\mathrm{N}$ & $\%$ & $\mathrm{~N}$ & $\%$ & & & & & & & \\
\hline \multicolumn{12}{|l|}{ Sex } \\
\hline Female & 63 & 75.0 & 21 & 25.0 & 0.019 & 1 & & 0.022 & 1 & & 0.005 \\
\hline Male & 15 & 51.7 & 14 & 48.3 & & 2.80 & $1.16-6.75$ & & 5.82 & $1.71-19.80$ & \\
\hline \multicolumn{12}{|l|}{ Age* } \\
\hline Range 1 & 41 & 71.9 & 16 & 28.1 & 0.501 & & & & & & \\
\hline Range 2 & 37 & 66.1 & 19 & 33.9 & & & & & & & \\
\hline \multicolumn{12}{|c|}{ Type of Relationship } \\
\hline Stable Union & 73 & 67.6 & 35 & 32.4 & 0.215 & & & & & & \\
\hline Other & 5 & 100.0 & $\mathrm{O}$ & 0.0 & & & & & & & \\
\hline \multicolumn{12}{|c|}{ Time in current relationship } \\
\hline$\leq 10$ years & 20 & 80.0 & 5 & 20.0 & 0.179 & 1 & & 0.185 & & & \\
\hline$\geq 11$ years & 58 & 65.9 & 30 & 34.1 & & 2.07 & $0.71-6.06$ & & & & \\
\hline \multicolumn{12}{|l|}{ Works** } \\
\hline No & 19 & 86.4 & 3 & 13.6 & 0.033 & 1 & & 0.043 & 1 & & 0.01 \\
\hline Yes & 37 & 61.7 & 23 & 38.3 & & 3.94 & $1.05-14.80$ & & 7.45 & $1.62-34.20$ & \\
\hline \multicolumn{12}{|l|}{ Social Class } \\
\hline Lower/Middle & 39 & 62.9 & 23 & 37.1 & 0.121 & 1 & & 0.123 & 1 & & 0.041 \\
\hline Upper & 39 & 76.5 & 12 & 23.5 & & 1.92 & $0.84-4.38$ & & 3.35 & $1.05-10.67$ & \\
\hline \multicolumn{12}{|l|}{ Smokes } \\
\hline No & 70 & 70.7 & 29 & 29.3 & 0.304 & & & & & & \\
\hline Yes & 8 & 57.1 & 6 & 42.9 & & & & & & & \\
\hline \multicolumn{12}{|c|}{ Is satisfied with his/her oral health } \\
\hline Yes & 55 & 77.5 & 16 & 22.5 & 0.012 & 1 & & 0.013 & 1 & & 0.029 \\
\hline No & 23 & 54.8 & 19 & 45.2 & & 2.84 & $1.25-6.47$ & & 3.45 & $1.13-10.51$ & \\
\hline \multicolumn{12}{|c|}{ Is satisfied with the appearance of his/her own teeth** } \\
\hline Yes & 55 & 76.4 & 17 & 23.6 & 0.019 & 2.65 & $1.59-6.05$ & 0.021 & & & \\
\hline No & 22 & 55.0 & 18 & 45.0 & & 1 & & & & & \\
\hline \multicolumn{12}{|c|}{ Self-perceives his/her quality of life as good } \\
\hline Yes & 68 & 71.6 & 27 & 28.4 & 0.178 & 2.02 & $0.72-5.65$ & 0.183 & & & \\
\hline No & 10 & 55.6 & 8 & 44.4 & & 1 & & & & & \\
\hline
\end{tabular}

*In 2011: Range 1 (20-44 years) and Range 2 (45-64 years); **tThe total is not 113 due to loss of data.

In the qualitative analysis, there was a greater balance between participants of both sexes in relation to the reasons that led them to be told by their partners to see the dentist. For this variable, it was possible to identify three categories, as follows:

Physiopathological Clinical Aspects

“Breath” (W03, H19, W135, M195) and “Odor” (W239).

"She tells me to when there is pain" (M151).

"Caries" (W18).

"She advised me not to get my teeth extracted and replace them with dentures, and I complied" (M136).

"Need of dentures" (W193).

Health-Related Habits

"[She] complains when I smoke" (M132) and "Smoking" (M187). 
Healthcare Aspects

"She's the one who always schedules visits to the doctor and dentist" (M128).

"Maintenance" (M92).

"One looks out for the other" (M224).

The reasons why the interviewees would tell their partners to see the dentist were more frequently expressed by the female participants. For this variable, it was possible to identify two categories, as follows:

Physiopathological Clinical Aspects

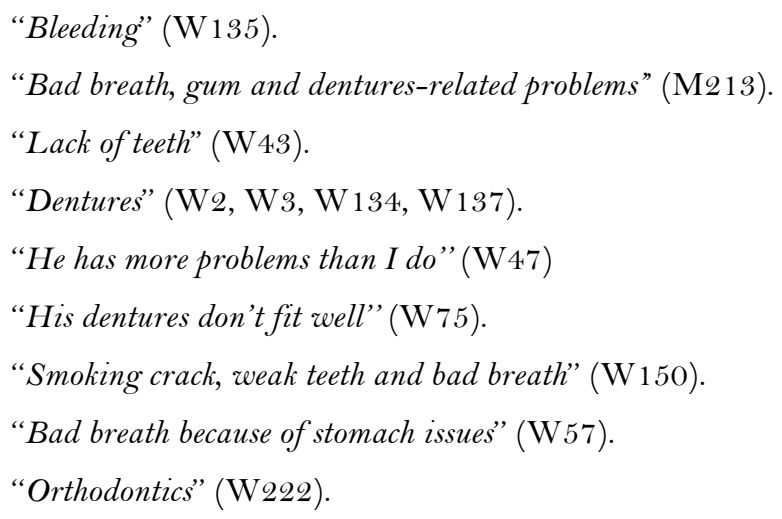

Healthcare Aspects

"Neglect on his part" (W82).

“When he doesn't show up to dental visits” (W108).

"To clean his teeth, if I don't tell him to he doesn't go" (W116), "Maintenance". (W3, M192) or "Check-ups" (M19, W214).

"For his own health, it's good for him" (W81).

\section{Discussion}

The present study showed that upper-class male individuals who work and are dissatisfied with their oral health are more likely to be told by their female partners to see the dentist. In addition, twice the number of interviewees who complained of their partners' oral health had told said partners to see the dentist. These findings demonstrate how women take care of their family as an expression of affection, and perhaps, for this reason, men have a historical perspective of care centered on the female figure [4], whether in childhood, when it is associated with the role of the mother and in adulthood, by transferring said association to the female partner. However, this may reinforce traditional gender roles, thus burdening modern women who are already inserted in other work-related scenarios [4,11].

Furthermore, men who deny vulnerability, pain and suffering reinforce a socially imposed symbolic space of division between the male and female universes [3,10]. This culturally established context causes men to seek health services less often, becoming more vulnerable to several morbidities, including oral diseases $[10,20]$. In this way, women become important in the strategy of male adherence to healthcare practices [4], as the present study showed that the act of telling one's partner to seek health services is associated with the female role; in fact, one of the men interviewed stated that it is always his female partner who schedules his visits to the doctor and dentist. 
A study has shown that there is no significant difference between the perception of oral health between men and women [9], as also found in the present study, seeing as the individuals who had been told to seek dental services reported being dissatisfied with their oral health. However, it was not this negative perception, but rather their partners' incentive that led them to schedule a dental visit. Therefore, this stigma may be related to issues that go beyond the ability to pay for dental services, as those who had been told to seek said services were upper-class workers. Although the ability to get a license seems to be a direct factor limiting the use of dental services, a study with a sample of workers showed that the frequency of dental visits was higher among women compared to men [9].

In this sense, we can see that in the present study, one of the main reasons for the participants (mainly the women) telling their partners to see a dentist was for prevention, referred to as cleaning, check-ups and maintenance. A study has found that men seek dental services almost exclusively for curative practices, while women adopt preventive practices [4]. In addition, women showed a tendency to perform less invasive procedures when, for example, one man reported that his partner had asked him not to remove his teeth and replace them with dentures. This aspect may derive from the idea that edentulism, even in the presence of dentures, negatively impacts quality of life [21]. Therefore, periodic monitoring by a dentist is essential to prevent problems such as caries and periodontal disease [11], and its main outcome, tooth loss. In this study, clinical aspects such as bleeding, caries, pain, lack of teeth and need for dentures were reported by the participants as reasons for them telling or being told by their partners to seek dental services.

The association between marital status and oral condition is still controversial in the literature, but both can help determine tooth loss. Studies show that individuals who live alone are more likely to have untreated teeth [15], possibly due to the lack of social support [22], therefore seeking dental services only in the case of pain or to undergo a full-mouth extraction [23]. Other studies show that married individuals are more likely to lose teeth $[15,16]$. This could be justified by the fact that the frequent use of dental services increases the exposure to interventions and overtreatment, and thus, to the repetitive restorative cycle, leading to greater loss of teeth [24].

Other relevant issues for the participants of this study telling their partners to seek dental services were bad breath and smoking. A study with older adults showed that halitosis compromises social relationships, including friendships and romantic, work and family relationships. This is because family members feel uncomfortable when addressing the issue, assigning this responsibility to the individual that shares the closest bond with the person in question, in this case, the spouse, due to the daily and more intimate interactions between them [25]. It is known that smoking, in addition to negative consequences for health in general, contributes to the onset of halitosis [26].

Halitosis can hinder intimacy in affective relationships due to the impossibility of close contact, creating a barrier between couples [25]. In addition, it can cause those affected to distance themselves from their family, especially their spouse, due to feelings of inferiority, loss of value and dysthymia, situations that are very harmful to aging individuals, with loss of empowerment and verbal autonomy, which are both essential for ensuring quality of life throughout the aging process [25].

A study has shown that although there are no differences between the general health habits of men and women, men who had better general health habits also performed better in relation to brushing their teeth daily [9], which is a relevant aspect, mainly due to the low value assigned to oral health [11]. Thus, the habit of brushing one's teeth can be influenced by other factors, such as the concern with their appearance [9]. This aesthetic demand can be observed in the report of one of the interviewees of this study, who told her partner to 
seek orthodontic treatment. The concern with the appearance of teeth seems to be greater in the female universe, as has been pointed out in other studies [9,13].

One of the limitations of this study is its cross-sectional nature, which does not allow us to infer causality. In addition, the sample size was calculated to assess oral health conditions, and the use of crosssectional data with a cohort design led to the loss of follow-up. In this first moment, the objective was to perform an initial exploratory analysis, and future studies should consider a sample calculation that is specific to this variable, with a better balance between the number of male and female participants. Despite these limitations, the present study shows a tendency to the distribution of higher proportions of healthcare among women compared to men in the descriptive analysis, but in the inferential analysis, the sample size may have been insufficient to address other issues.

Another limitation is the fact that all the volunteers were in hetero-affective relationships, so we were unable to represent individuals in homo-affective relationships in our results. Further research is needed in this regard, so that we can plan better public health policies and ensure that the strategies used by the healthcare network strengthen male adherence.

A review has made it clear that the notion of gender, i.e., of the male and female universes, is still under construction and can thus be changed; therefore, the discussion of dichotomous representation must be part of clinical practice and considered in studies, so as to neutralize the gender bias among health professionals and ensure the provision of more equitable care [5].

A gender study with dental scholars in three different decades has shown that the behavior of young people is changing, with significant improvement in health behaviors, such as higher frequency of tooth brushing and periodic visits to the dentist, and a significant reduction in conditions such as biofilm, caries and periodontal disease over the years, as well as in the disparity between men and women regarding the frequency of tooth brushing and presence of biofilm, the association between which was found only in the 1980s [27].

In this sense, more epidemiological studies should be carried out in the future, considering the role of women as predictors of their male partners' oral health and the validity of the use of this information as an epidemiological oral health indicator. A study has shown that for older adults, individual self-perception is a valid form of assessment of their oral health condition, without the need for clinical evaluation [28]. When it is not possible for older adults to be examined by a health professional, their self-perception has been used due to its high degree of accuracy in relation to the actual oral situation. Would the perception of women also be a valid indicator for assessing the oral health of their male partners? This issue becomes even more pertinent considering that men seek oral services and participate in epidemiological oral health studies less often and that this is a difficult population to include in epidemiological studies, especially in the economically active age group.

\section{Conclusion}

In the quantitative analysis, upper-class men who worked and were dissatisfied with their oral health were found to be more likely to be told by their female partners to see the dentist. Future studies should explore whether women are predictors of care, and the validity of this information as an indicator of the oral health condition of their male partners. The reasons for telling or being told by one's partner to see the dentist were related to clinical and behavioral health aspects. 


\section{Authors' Contributions}

\begin{tabular}{|c|c|c|}
\hline MFSJ & (iD) https://orcid.org/0000-0001-8837-5912 & $\begin{array}{l}\text { Conceptualization, Methodology, Formal Analysis, Investigation, Data Curation and Writing - } \\
\text { Original Draft. }\end{array}$ \\
\hline CLC & (iD) https://orcid.org/0000-0002-0087-6868 & Writing - Original Draft. \\
\hline МНB & (iD) https://orcid.org/0000-0003-1310-6771 & Writing - Original Draft. \\
\hline MJB & (iD) https://orcid.org/0000-0002-0379-3742 & $\begin{array}{l}\text { Conceptualization, Methodology, Writing - Review and Editing, Supervision, Project } \\
\text { Administration and Funding Acquisition. }\end{array}$ \\
\hline MLRS & https://orcid.org/0000-0002-034.6-5060 & Conceptualization, Writing - Review and Editing, Supervision and Project Administration. \\
\hline
\end{tabular}

\section{Financial Support}

This work was supported by the São Paulo Research Foundation (Fundação de Amparo à Pesquisa do Estado de São Paulo - FAPESP) (Grant number 2014/15184-2).

\section{Conflict of Interest}

The authors declare no conflicts of interest.

\section{Data Availability}

The data used to support the findings of this study can be made available upon request to the corresponding author.

\section{References}

[1] Bruschini C, Lombardi MR. Banco de dados sobre o trabalho das mulheres. Fundação Carlos Chagas. Available from: https://www.fcc.org.br/bdmulheres/. [Accessed on March 18, 2020]. [In Portuguese].

[2] Silva EA, Almeida SSC. Woman and work in the contemporary world: space conquest and implications for healthdisease process. Hitória Cult 2017; 6(3): 306-24. https://doi.org/10.18223/hiscult.v6i3.2019

[3] Keijzer B. Hasta Donde el Cuerpo Aguante: Género, Cuerpo y Salud Masculina. In: Caceres C, Cueto M, Ramos M, Vallens S (Org.). La Salud Como Derecho Ciudadano: Perspectiva y Propuestas Desde América Latina. Lima: Facultad de Salud Publica y Administración de la Universidad Peruana Cayetano Herida; 2003. p. 137-152. [In Spanish].

[4] Machin R, Couto MT, Silva GSN, Schraiber LB, Gomes R, Figueiredo WS, et al. Concepts of gender, masculinity and healthcare: a study of primary healthcare professionals. Ciênc Saúde Colet 2011; 16(11):4503-12. https://doi.org/10.1590/S1413-81232011001200023

[5] Samulowitz A, Gremyr I, Eriksson E, Hensing G. "Brave men" and "Emotional women": A theory-guided literature review on gender bias in health care and gendered norms towards patients with chronic pain. Pain Res Manag 2018; 2018:e6358624. https://doi.org/10.1155/2018/6358624

[6] Couto MT, Schraiber LB. Homens, Saúde e Violência: Novas Questões de Gênero no Campo da Saúde Coletiva. In: Minayo MCS, Coimbra Junior CEA (Org.). Críticas e Atuantes: Ciências Sociais e Humanas em Saúde na América Latina. Rio de Janeiro: Fiocruz; 2005. p. 687-706. [In Portuguese].

[7] Wang Y, Hunt K, Nazareth I, Freemantle N, Petersen I. Do men consult less than women? An analysis of routinely collected UK general practice data. BMJ Open 2013; 3:e003320. https://doi.org/10.1 136/bmjopen-2013-003320

[8] Hunt K, Adamson J, Hewitt C, Nazareth I. Do women consult more than men? A review of gender and consultation for back pain and headache. J Health Serv Res Policy 2011; 16(2):108-17. https://doi.org/10.1258/jhsrp.2010.009131

[9] Fukai K, Takaesu Y, Maki Y. Gender differences in oral health behavior and general health habits in an adult population. Bull Tokyo Dent Coll 1999; 40(4):187-93. https://doi.org/10.2209/tdcpublication.40.187

[10] Gomes RG, Nascimento EF, Araújo FC. Why do men use health services less than women? Explanations by men with low versus higher education. Cad Saude Publica 2007; 23(3):565-74. https://doi.org/10.1590/So102-311X2007000300015

[11] Bulgareli JV, Faria ET, Cortellazzi KL, Guerra LM, Meneghim MC, Ambrosano GMB, et al. Factors influencing the impact of oral health on the daily activities of adolescents, adults and older adults. Rev Saúde Pública 2018; 52:44. https://doi.org/10.11606/s1518-8787.2018052000042

[12] Miettinen O, Lahti, S, Sipilä K. Psychosocial aspects of temporomandibular disorders and oral health-related qualityof-life. Acta Odontol Scand 2012; 70(4):331-6. https://doi.org/10.3109/00016357.2011.654241

[13] Choi SH, Kim BI, Cha JY, Hwang CJ. Impact of malocclusion and common oral diseases on oral health-related quality of life in young adults. Am J Orthod Dentofacial Orthop 2015; 147(5):587-95. https://doi.org/10.1016/j.ajodo.2014.12.025

[14] Castilho ARF, Mialhe FL, Barbosa TS, Puppin-Rontani RM. Influence of family environment on children's oral health: a systematic review. J Pediat 2013; 89(2):116-23. https://doi.org/10.1016/j.jped.2013.03.014 
[15] Avlund K, Holm-Pedersen P, Morse DE, Viitanen M, Winblad B. Social relations as determinants of oral health among persons over the age of 80 years. Community Dent Oral Epidemiol 2003; 31(6):454-62. https://doi.org/10.1046/j.1600-0528.2003.00115.x

[16] De Marchi RJ, Hilgert JB, Hugo FN, Santos CM, Martins AB, Padilha DM. Four-year incidence and predictors of tooth loss among older adults in a southern Brazilian city. Community Dent Oral Epidemiol 2012; 40(5):396-405. https://doi.org/10.1111/j.1600-0528.2012.00689.x

[17] Silva-Junior MF, Sousa MLR, Batista MJ. Prospective cohort of adult oral health in Piracicaba, SP, Brazil. BMC Res Notes 2019; 12:221. https://doi.org/10.1186/s13104-019-4243-y

[18] Graciano MIG, Lehfeld NA, Neves Filho A. Critérios de avaliação para classificação socioeconômica: elementos de atualização. Serv Social Realidade 1999; 8(1):109-28. [In Portuguese].

[19] Bardin L. Análise de Conteúdo. 3. ed. São Paulo: Edições 70; 2016. [In Portuguese].

[20] Bourdieu P. A dominação masculina. Rio de Janeiro: Bertrand Brasil; 1999. [In Portuguese].

[21] Emami E, de Souza RF, Kabawat M, Feine JS. The impact of edentulism on oral and general health. Int J Dent 2013; 2013:e498305. https://doi.org/10.1155/2013/498305

[22] Locker D, Gibson B. Discrepancies between self-ratings of and satisfaction with oral health in two older populations. Community Dent Oral Epidemiol 2005; 33(4):280-8. https://doi.org/10.1111/j.1600-0528.2005.00209.x

[23] McGrath C, Bedi R. Influences of social support on the oral health of older people in Britain. J Oral Rehab 2002; 29(10):918-22. https://doi.org/10.1046/j.1365-2842.2002.00931.x

[24] Silva-Junior MF, Batista MJ, Fonseca EP, Sousa MLR. Spatial distribution of tooth loss in a population of adults. Rev Gaúcha Odontol 2017; 65(2):115-20. https://doi.org/10.1590/1981-8637201900006352 1

[25] Coelho EF. A vivência da halitose e seus impactos na autoestima, autoimagem e autoconceito do idoso e nas suas relações sociais. [Dissertation]. Universidade Católica de Brasília: Programa de Pós-Graduação Stricto Sensu em Gerontologia; Brasília; 2010. [In Portuguese].

[26] Leandri TP, Boek EM, Ricci HA, Andrade MF, Cerqueira-Leite JBB. Personal perception of assessment for the condition of halitosis and clinical confirmation. Rev Odontol UNESP 2015; 44(5):299-304. https://doi.org/10.1590/1807-2577.0087

[27] Mamai-Homata E, Koletsi-Kounari H, Margaritis V. Gender differences in oral health status and behavior of Greek dental students: A meta-analysis of 1981, 2000, and 2010 data. J Int Soc Prev Community Dent 2016; 6(1):60-8. https://doi.org/10.4103/2231-0762.175411

[28] Arenas-Márquez MJ, Tôrres LHN, Silva DD, Hilgert JB, Hugo FN, Neri AL, et al. Validity of self-report of oral conditions in older people. Braz J Oral Sci 2019; 18:e191670. https://doi.org/10.20396/bjos.v18io.8657271 